\title{
Public health implications of lead poisoning in backyard chickens and cattle: four cases
}

This article was published in the following Dove Press journal:

Veterinary Medicine: Research and Reports

2 April 2013

Number of times this article has been viewed

\section{Amber Roegner' \\ Federico Giannitti ${ }^{2}$ \\ Leslie W Woods ${ }^{2}$ \\ Aslı Mete ${ }^{2}$ \\ Birgit Puschner ${ }^{1,2}$}

'Department of Molecular Biosciences, School of Veterinary Medicine, University of California, Davis, CA, USA; ${ }^{2}$ California Animal Health and Food Safety Laboratory System, School of Veterinary Medicine, University of California, Davis, CA, USA
Correspondence: Birgit Puschner Department of Molecular Biosciences and the California Animal Health and Food Safety Laboratory System, School of Veterinary Medicine, University of California,

I 20 Haring Hall, Davis,

CA 95616 , USA

Tel +l 5307526285

Fax +I 5307524698

Email bpuschner@ucdavis.edu
Abstract: Lead intoxication in livestock has historically been associated with cattle turned out to pasture and accidental ingestion of lead from drinking crankcase oil, licking grease from machinery, chewing on plumbing or batteries, or drinking water contaminated from leaching materials. Even with the decrease in manufactured items produced with lead, contaminants persist in the landscape and may enter the food supply through animal products. Changing patterns of open range herds moving to new pasture and the increased popularity of urban/suburban backyard chickens or other livestock necessitates public awareness about the clinical signs of lead intoxication, the potential for subclinical animals, public health concerns, particularly for exposure in children, and testing options available. Cases of lead intoxication in livestock demand a thorough case work-up to identify all sources of lead, address subclinical cases, evaluate risk to consumers, and make management suggestions for future prevention. We discuss four recent cases of confirmed lead poisoning in backyard chickens and open range cattle and assess the public health implications therein. Taken as a whole and considering the potential of the remaining herd or flock to be affected without necessarily showing signs, public health officials and veterinarians should be prepared to advise clients on case work-up and management and prevention considerations. Backyard chickens and cattle may not present for suspected lead poisoning as in several of the cases discussed herein yet may still contain concerning tissue or blood levels. The authors believe increased surveillance through heavy metal screens is crucial to adequately protect public health.

Keywords: bovine, diagnosis, plumbism, residue, toxicosis, poultry

\section{Introduction}

The diverse sources of lead in the environment leading to potential human and animal intoxication are widespread. ${ }^{1,2}$ They include discarded manufactured materials such as lead shot, batteries, oil, gasoline, crank cases, and in-use manufactured items such as lead-containing paints, chips and wood, in addition to variable amounts present in air, soil, water, and food (either contaminated feed, meat or animal products or canned foods). ${ }^{1,2}$ With inhalation and ingestion as exposure routes, animals in the environment have the potential to act as sentinels for lead contamination of water, air, and soil,,$^{3-7}$ but also to contribute to the total lead burden in the food supply chain through meat, milk, and egg products. ${ }^{8}$ Young children, like all young animals, are particularly susceptible to the acute and chronic effects of lead poisoning and repeated trace exposures through the environment or food, which can result in intellectual impairment and delayed neurodevelopment. ${ }^{9}$ Thus, alerting owners of small backyard flocks or production animals of potential risks with lead contaminated eggs, meat, submit your manuscript $\mid$ www.dovepress.com

Dovepress

http://dx.doi.org// 0.21 47/VMRR.S36083
(C) 2013 Roegner et al, publisher and licensee Dove Medical Press Ltd. This is an Open Access article which permits unrestricted noncommercial use, provided the original work is properly cited. 
or milk is particularly important. In addition, it is critical to recognize clinical signs of affected animals and perform a thorough work-up of any suspected lead poisonings, including identification of source and subclinical animals that still may contain considerable levels of lead.

Clinical signs of acute lead poisoning in cattle are typically associated with dysfunction of the nervous system including ataxia, blindness, salivation, eyelid twitching, jaw champing, bruxism, muscle tremors, and convulsions within 24 to 48 hours of exposure. ${ }^{10}$ Subacute or chronic lead poisoning is usually characterized by a combination of nervous and gastrointestinal signs: anorexia, rumen stasis, dullness, transient constipation followed by diarrhea, blindness, head pressing, bruxism, hyperesthesia, and incoordination. ${ }^{11}$ In all species, juveniles are much more susceptible than adults. Dairy animals in particular represent a concern as lead concentrations in milk have been shown to correspond directly with blood lead concentrations; milk has the potential to be contaminated with lead well after exposure due to sequestration of lead into bone and eventual posterior bone resorption and mobilization by hypocalcemic heifers and cows. ${ }^{12,13}$ Scant information regarding the kinetics of lead in blood and withdrawal times for beef cattle exposed to lead exists in the literature, with reliable data available only for monogastrics. Despite removal from source contamination, the rumen can serve as a site for ongoing exposure; in addition, deposition in and subsequent release from bone necessitates expensive and continuing testing to determine if an animal is truly lead free.

Clinical signs of acute lead poisoning in chickens include muscle weakness, ataxia, loss of appetite, marked weight loss, and eventual drop in egg production and/or severe anemia. ${ }^{14}$ Chronic exposures may also result in degeneration of motor nerves in the spinal cord and axonal loss in peripheral nerves, along with muscle atrophy and myodegeneration. ${ }^{15}$ Even trace levels of lead in the diet $(1.0 \mathrm{mg} / \mathrm{kg})$ can result in growth retardation. ${ }^{16}$ Ingested lead results in elevated blood levels and deposition in bone, soft tissues and eggs, with the highest concentrations in liver and kidney. ${ }^{17}$

The increased trend of backyard chickens in urban or suburban areas potentially exposed to lead-based paints, in housing, or bedding or from contaminated soil has raised concern in the popular press recently. ${ }^{18}$ In addition to the concern over the accumulation of trace amounts of lead over time in humans, of particular concern is the potential for children to be exposed through egg consumption from contaminated family-owned flocks. The acute neurotoxic effects of lead exposure in children have been well established and even chronic exposures may result in abnormal neurodevelopment. ${ }^{19-22}$

Lead poisoning of livestock from both contamination of feed items ${ }^{23}$ and free-range access to discarded lead-based paints, lead contaminated wastes (batteries, putty, asphalt products, leaded gasoline, spent oil, and lead shot; Figure 1) or even industrial waste has been well documented. ${ }^{24-31}$ However, the US Food and Drug Administration (FDA) has not established regulatory limits for concentrations of trace metals in edible tissues of livestock and poultry, with the exception of arsenic, which has been monitored by the Food Safety and Inspection Service (FSIS) of the US Department of Agriculture (USDA) since the 1970s. Rather, in production settings, acceptable limits are determined on an individual basis by the FDA. However, multiple sources of lead exist in the environment and, while an animal that inhales or ingests a concentrated source may develop acute lead toxicosis, it is likely that many exposures remain subclinical. These exposures in particular pose a potential threat to public health through contaminated edible tissues or animal products. Just in the past 3 years alone (2010-2012), we confirmed either lead exposure or intoxication in 13 cases from eleven backyard chicken flocks, and eight incidents from seven different cattle operations in 15 different counties in California (Figure 2). While these confirmed cases reflect overall trends, due to reporting and diagnostic work-up constraints, they do not represent the true frequency of incidents of lead poisoning. We suspect that lead exposure is likely underestimated, especially in backyard poultry, because of lack of routine diagnostic procedures in sick or deceased birds, and because testing for lead is not routinely performed.

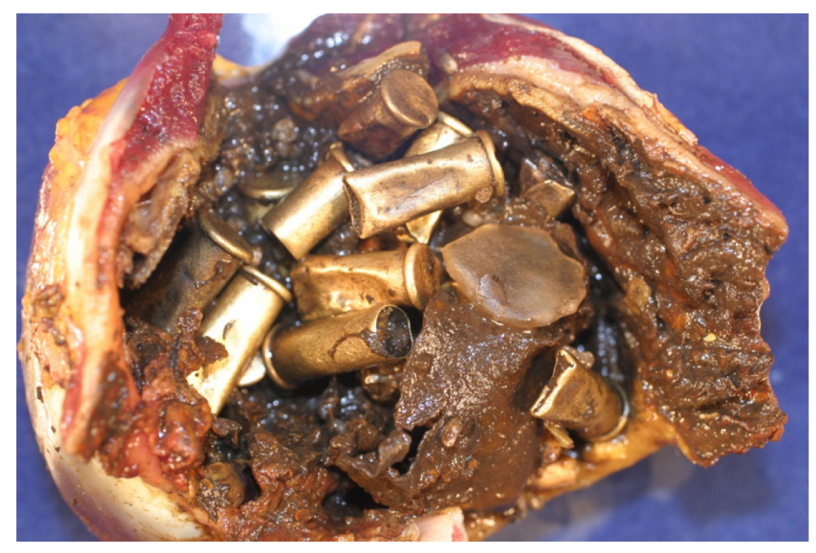

Figure I Gizzard of a 20-week-old chicken containing 19 mostly intact 0.22 rim fire shell casings. Case not part of this case series. Image for illustration purposes only. Notes: The bird died from lead poisoning, confirmed by liver lead concentration of $22 \mathrm{mg} / \mathrm{kg}$ wet weight, had weight loss, inappetence, and listlessness, and was the seventh chicken from this flock to have died. Free-ranging flock $\left(4047 \mathrm{~m}^{2}\right)$ with coop in Kern County, CA, USA. 


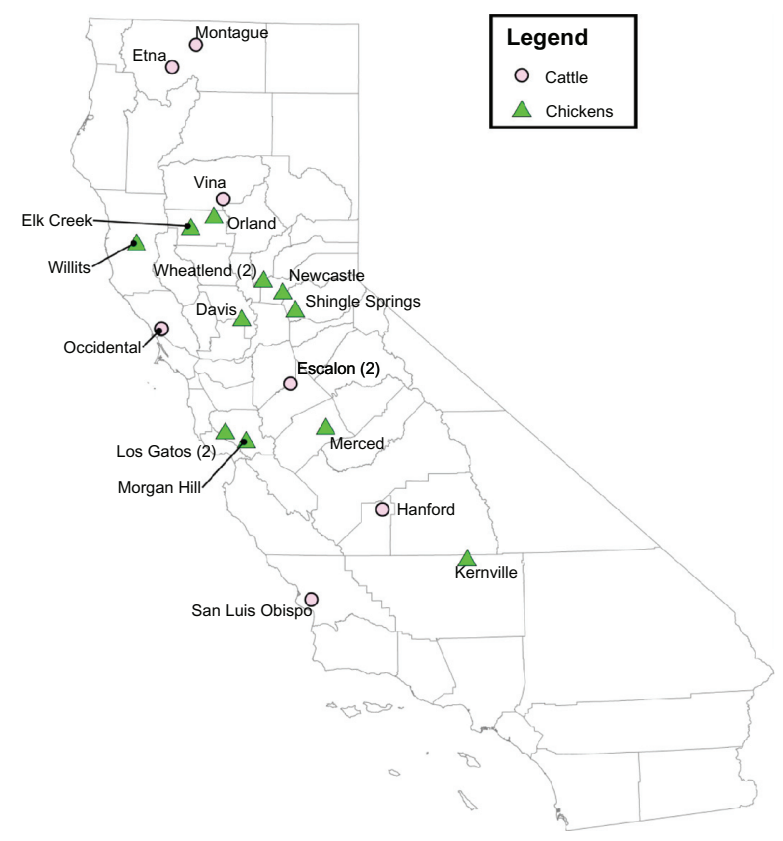

Figure 2 Location of 21 diagnosed lead exposures in cattle (eight incidents) and backyard chickens ( 13 incidents) in 15 different California counties (Glenn, Mendocino, Kern, Merced, Yolo, Santa Clara, Yuba, El Dorado, Placer, Siskiyou, Tehama, Kings, San Joaquin, Sonoma, and San Luis Obispo) between January I, 2010 and December 31, 2012.

The review of recent cases, in addition to emerging trends in urban-based farms, suggests the need for public awareness and guidance on prevention and management, recognition of potential sources of lead contamination, testing procedures, and public health risks. Here we present several recent cases of lead poisoning in backyard chickens and cattle from the California Animal Health and Food Safety Laboratory (CAHFS) at the University of California, Davis presented during 2012 and discuss the public health implications therein. Our data suggest that subclinical lead poisoning in backyard chickens and cattle may pose a substantial public health risk; veterinarians and public health officials should be aware of this risk and offer testing resources and management guidelines for prevention. The prevalence of subclinical lead poisoning in domestic species may be higher than previously believed. In addition, we recommend increased surveillance with heavy metal screens, particularly in backyard chickens and eggs. Often animals may present for reasons other than lead toxicosis and are only diagnosed secondarily through a thorough work-up. Client education is key.

\section{Materials and methods Case studies Case I}

A 10-month-old beef steer from a herd of 200 on rangeland in Tehama County, CA presented to the veterinary practitioner in January 2012 with sudden onset of lethargy, hanging head and coughing of 5 days duration. One other animal had died several weeks prior with similar clinical signs. The animal was treated with tulathromycin (Draxxin ${ }^{\mathrm{TM}}$, Pfizer Inc., New York, NY, USA) and acetylsalicylic acid (Aspirin ${ }^{\mathrm{TM}}$, Bayer, Morristown, NJ, USA), but was euthanized 72 hours after presentation due to lack of response to treatment. The steer had been vaccinated at 3 months of age and weaning with unknown vaccines. The rest of the program was reported to be an "organic" operation, free range and grass fed with no dewormers or chemical substances used. The liver lead concentration of the animal was $21 \mathrm{mg} / \mathrm{kg}$ wet weight, a concentration consistent with lead poisoning. All other metal concentrations, including manganese, cadmium, copper, iron, zinc, molybdenum, arsenic, mercury, and selenium were within acceptable concentrations for cattle liver. No significant gross or histologic findings were seen in submitted sections of lung, spleen, kidney, and rumen. The liver had undergone advanced autolysis and could not be reliably evaluated histologically. Bovine Viral Diarrhea Virus (BVDV) polymerase chain reaction was negative and all bacteriology testing performed was unremarkable.

This steer did not present with clinical signs suggestive of lead poisoning, and no gross or microscopic lesions were seen that would suggest lead poisoning (such as cortical laminar necrosis). Routine analysis for trace metals was performed on the liver of this steer as deficiencies, especially copper and selenium, are common in California beef herds. Lead toxicosis was diagnosed serendipitously in this case as lead is one of the analytes included in the trace metal test. Thus, this case demonstrates that lead poisoning can be an unexpected finding in cases with atypical historical information as well as non-specific pathological findings. Additionally, this case illustrates the need for withdrawal times of cattle from herds exposed to a lead source in their environment. A previous study of herds with clinical cases of lead poisoning found that $7 \%-40 \%$ of asymptomatic cattle had blood lead $\geq 0.1 \mu \mathrm{g} / \mathrm{mL} .{ }^{32}$ Reported half-lives $\left(\mathrm{t}_{1 / 2}\right)$ of lead in blood of exposed cattle is quite variable; a retrospective study in accidental environmental exposures found shorter $t_{1 / 2}$ in lactating cattle versus non-lactating cattle. ${ }^{33}$ The range of $t_{1 / 2}$ was variable from 48 to 2507 days; previously reported $t_{1 / 2}$ of lead in blood was 1-2 months. ${ }^{34}$ Variability can be due to a range of factors, including failure to identify all sources of lead contamination or removal of animals from the lead source, and previously mentioned factors of retention of lead in the rumen and reticulum as well as uptake into and release from bone. Chelation therapy with calcium EDTA or a rumenotomy may 
help reduce blood-lead levels in cattle but adds considerable cost for the owners. In addition, chelation therapy does not necessarily remove sufficient amounts of lead from tissues and is unlikely to reverse lead-induced tissue damage. The risk with chelation therapy is remobilization of lead from tissue stores and temporary worsening of clinical signs.

The federal government does not regulate blood lead levels in production animals and states vary considerably in reporting guidelines and requirements. For example, in Michigan lead poisoning is a reportable disease and lead intoxicated cattle must be quarantined and only released when they test negative for blood level $(<0.05 \mu \mathrm{g} / \mathrm{mL}) .{ }^{33}$ Blood lead testing is repeated every 3 months and owners can accrue great costs during quarantine. The cost may deter individuals from doing proper testing on potentially subclinical animals in cases that go unreported. More information on factors specifically influencing the toxicokinetics of blood lead levels in cattle would be particularly helpful and reduce cost for public health departments and herd owners. Recent work evaluating delta-aminolevulinic acid (ALA) in cattle suggests plasma ALA may be a good biomarker of blood lead levels. ${ }^{35}$ One of the main mechanisms by which lead causes toxicosis is the inhibition of aminolevulinic acid dehydratase, involved in the dimerization of ALA to form porphobilinogen in red blood cells. In humans, plasma and blood ALA activity has been a useful parameter for determination of trace exposures to lead $(<0.01 \mu \mathrm{g} / \mathrm{mL})$. Plasma ALA activity could be useful along with testing blood lead concentrations for the identification of subclinical cattle. Cattle may undergo minimal to little medical treatment if signs of toxicosis are not evident. Ending exposure by identifying the environmental source and either removing it or removing the cattle from it is critical for proper management. However, there is a current major gap in understanding withdrawal times for subclinical cases. The development of a reliable biomarker could facilitate the knowledge of factors influencing $t_{1 / 2}$, thereby reducing costs for public health officials and owners.

\section{Case 2}

Necropsy of a brown adult female chicken was performed on January 18, 2012. The chicken came from a backyard flock in Santa Clara County, CA, USA and had been found down and presumed injured and did not respond to supportive care. The chicken had poor body condition with bilateral atrophy of the pectoral muscles and little body fat. Pathological findings included ovarian adenocarcinoma with metastasis to the peritoneum and serosal surfaces of the intestines and pancreas (carcinomatosis), and a leiomyoma of the mesosalpinx. Both forms of neoplasia occur frequently in adult laying hens. The liver was flaccid (atrophy), the crop was empty and the brain, oral cavity, infraorbital sinuses, larynx, esophagus, trachea, heart/pericardium, syrinx, thyroid glands, kidneys, air sacs, proventriculus, gizzard, and spleen were all unremarkable. Toxicological findings included high hepatic levels of lead ( $7.8 \mathrm{mg} / \mathrm{kg}$ wet weight) and elevated hepatic iron concentrations (3700 mg/kg wet weight), likely associated with congestion or fasting. Liver manganese, cadmium, copper, zinc, molybdenum, arsenic, and mercury were not detected in toxic levels. The detected liver lead concentration was consistent with exposure to or intoxication from lead. Diagnostic tissue lead concentrations associated with clinically apparent lead intoxication are quite variable and differ between species. Liver and/or kidney lead concentrations consistent with intoxication are often $>6 \mathrm{mg} / \mathrm{kg}$ wet weight and can exceed $10 \mathrm{mg} / \mathrm{kg}$ wet weight. ${ }^{36}$ No infectious agents were found with routine microbiological work-up.

The likely cause of death in this chicken was lead intoxication but may have been complicated by concurrent neoplasia and poor body condition, suggesting the potential for subclinical cases remaining within the same flock. The owner was instructed to identify the source of lead and avoid further exposure to other chickens or animals on the property. The owner was also advised that the case warranted testing blood levels of other animals and lead levels in eggs. Eggs from this backyard flock were submitted to CAHFS in April 2012. The egg content, mixed yolk and albumin, was analyzed and contained $0.072 \mathrm{mg} / \mathrm{kg}$ wet weight (or $72 \mu \mathrm{g} / \mathrm{kg}$ ) of lead. The client was advised that lead ingested by chickens is deposited in bones, soft tissues, and eggs and that lead contamination poses a potential public health risk particularly to children repeatedly consuming egg or edible chicken tissues. In a previous study, blood lead concentrations corresponded well with egg yolk levels in poultry exposed to lead-based chips; egg shells contained yet higher levels. The highest concentration of lead was found in the kidney, followed by liver, ovarian tissue, and finally muscle with the least contamination. ${ }^{17}$ However, limited information on the kinetics of lead in exposed chickens and implications for poultry meat or egg contamination is available. Further work needs to be performed to determine $t_{1 / 2}$ in backyard chicken flocks to assess when and if the eggs or meat may be safe for consumption by families, particularly children. More importantly, similar subclinical cases may occur more frequently than diagnosed and the public should be educated with respect to risks of potential lead ingestion by flocks. In this case, lead toxicosis was not suspected but discovered only secondary to a thorough work-up, including a 
heavy metal screen. We suggest a heavy metal screen as part of a full diagnostic work-up for any presenting backyard chicken in order to rule out public health risk for the consumers, even if lead toxicosis is not suspected to be the primary cause of death or illness.

Although testing of soil and other potential lead-based materials was recommended, no material was submitted for analysis; thus, the source of lead exposure in this flock was not identified. Based on all findings, the owners were advised to pursue potential human exposure to lead from consumption of eggs with their physician. Blood lead concentrations in humans, particularly children, should be followed by a primary care physician in cases of concern; children should not consume more than $6 \mu \mathrm{g}$ of lead per day from all sources. ${ }^{37}$ Taking into account the lead concentration measured in the egg submitted from this flock, one single average size $60 \mathrm{~g}$ egg without the shell contains $4.3 \mu \mathrm{g}$ of lead. This concentration is close to the threshold of $6.0 \mu \mathrm{g}$ of lead per day from all dietary sources that should not be exceeded especially in children less than 6 years of age and pregnant women. The Centers for Disease Control now considers blood lead levels less than $10 \mu \mathrm{g} / \mathrm{dL}$ $(0.1 \mu \mathrm{g} / \mathrm{mL})$ potentially toxic for both children and pregnant women, with new recommendations moving toward $5 \mu \mathrm{g} / \mathrm{dL}$ as the action level for health care and public health providers. ${ }^{38}$ The owner of the flock of this case was provided with contact information for the Childhood Lead Poisoning Prevention Programs in California. ${ }^{39}$ Similar resources can be identified with the help of local health departments. This case suggests the potential for chronic and cumulative exposures to occur over time with family-owned flocks and warrants periodic testing of eggs in any case uncertain of lead exposure.

\section{Case 3}

In April 2012, seven out of 15 backyard hens/chickens died acutely without showing previous clinical signs. The flock, located in El Dorado County, CA, USA, was housed in a raised and enclosed, but ventilated coop with boxes and a roost. All were producing eggs well except one that was thin and weak. One bird had been found dead several weeks prior. Four more died a couple of days later, all on the same afternoon after laying eggs in the morning and one 3-year-old female chicken was submitted for necropsy and toxicological testing. Gross evaluation of the hen in good nutritional body condition revealed skin wounds in multiple locations of the body, a fracture of the right third rib and extensive unilateral thoracic hemorrhage most consistent with trauma, which was the likely cause of death. There was also marked rounding of the heart with enlarged ventricular chambers as well as thinning of the left ventricular free wall, likely due to a congenital atrioventricular septal defect that was approximately $2 \mathrm{~mm}$ and had fibrosed edges. Additionally there was mild endocardiosis that was considered incidental. The significance of the cardiac pathology in this hen was undetermined. Toxicological findings included an elevated lead concentration in liver $(5.4 \mathrm{mg} / \mathrm{kg}$ wet weight) and kidney (12 mg/kg wet weight). Liver manganese, cadmium, copper, iron, zinc, molybdenum, arsenic, mercury and selenium concentrations were acceptable or non-toxic for poultry.

As discussed, diagnostic tissue lead concentrations can be quite variable and differ between species. However, liver and kidney lead concentrations consistent with intoxication are often $>6 \mathrm{mg} / \mathrm{kg}$ wet weight. Tissue concentrations associated with subclinical lead intoxication have not been well defined. While liver and kidney lead concentrations are often similar, they can sometimes differ depending on the duration of exposure to lead and time between exposure and sampling. In cases of chronic lead exposure, kidney lead concentrations typically exceed liver lead concentrations; thus, testing both liver and kidney samples is often recommended, particularly in suspected chronic scenarios. The lead concentrations in the liver and kidney of this chicken were consistent with lead toxicosis and suggestive of chronic exposure because of the elevated kidney concentration.

Similar recommendations were made to the owner as in case 2. This case again illustrates one very important take-home message: lead exposures in backyard chickens may be chronic and subclinical. As such, these exposures are incidental findings in the diagnostic work-up of cases and not based on a high suspicion of lead poisoning; lead residues in edible tissues are a serendipitous discovery. With the increased allowances to raise backyard chickens comes a need for periodic screening of eggs or testing of blood levels of chickens, particularly in small flocks or back yard settings where birds have free access to a host of potential sources. In addition, client or public education about this potential hazard from backyard flocks should be addressed.

\section{Case 4}

In April 2012, 40 Holstein heifers were moved to a new pasture in San Joaquin County, CA, USA. Three days later, three heifers were found dead and within a week, nine more heifers had died. Remaining heifers presented with ataxia, head pressing, recumbency, and paddling. Discarded flowers (identified as common peonies, Paeonia officinalis) and a discarded metal bucket were found in the pasture. Two 12-month-old heifers were submitted for necropsy, both approximately $272 \mathrm{~kg}$. Gross observations included petechiation of the epicardium 
and endocardium and few pleural adhesions in one heifer and thick white froth in the tracheal lumen and few chronic pleural adhesions in the other heifer. The rumen contents were mostly forage with little grain. The brains from both heifers did not fluoresce with ultraviolet light but microscopically both heifers had multifocal, acute neuronal necrosis in the cerebral cortical laminae (cortical laminar necrosis, polioencephalomalacia), compatible with lead toxicosis.

Both heifers had toxic liver lead concentrations (32 mg/kg wet weight and $11 \mathrm{mg} / \mathrm{kg}$ wet weight). The source was "lead grease" (Figure 3) present in the bucket that was found in the pasture and submitted along with pasture plants and the two carcasses. The lead grease contained $180,000 \mathrm{mg} / \mathrm{kg}$ of lead ( $18 \%$ lead). Plants initially considered potentially toxic were ruled out as a cause for mortality in this herd. Ocular fluids (aqueous humor) collected from both heifers did not contain detectable nitrate or nitrite, ruling out nitrate intoxication. Low numbers of gastrointestinal parasites were found associated with mild enteritis and multifocal, crypt necrosis. The animals were negative for BVDV by polymerase chain reaction. There were no other significant changes in the tissues of these heifers to suggest any other concurrent disease or other toxins that may target other organs. The owners were advised to check the property for other similar sources.

Remaining cattle had the potential to be subclinical so the owners were advised to spot test for blood lead levels. Direct correlation between blood and milk lead levels has been demonstrated, ${ }^{40}$ posing a potential health risk, but in this case, the animals were not to be bred for several months and would not enter the milk production stream for another 12 months. At that time, it would be unlikely for lead to remain an issue but still advisable to test milk upon lactation.

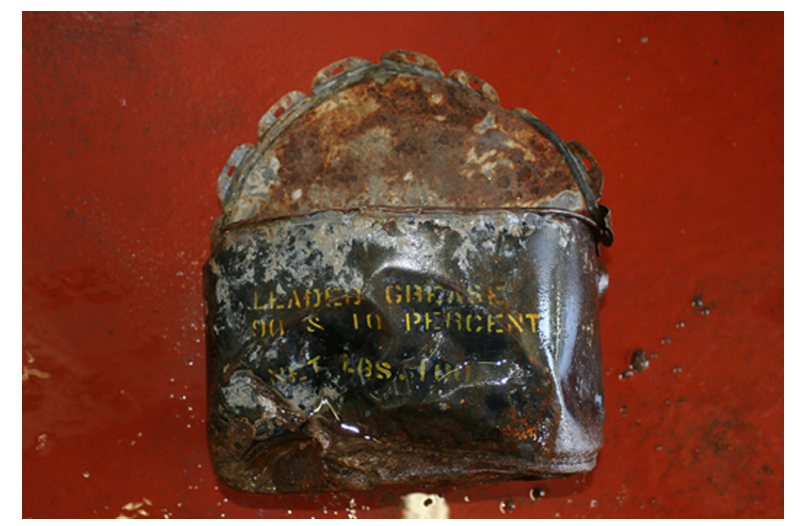

Figure 3 Metal container recovered from the pasture where twelve heifers were found dead.

Notes: Lead toxicosis was confirmed in two of the cattle by diagnostic testing. The other ten cattle from the same herd, presumably also intoxicated with lead, died within the same week. Grease from the container contained $18 \%$ lead.
There would be the potential for mobilization of lead from bone post parturition, so the dams should be tested again for blood lead concentrations at that time, although previous literature suggests the increase is minimal. ${ }^{34}$

However, in this particular case, the presumably 12 leadcontaminated carcasses detailed the most pressing public health concern. As liver and kidney concentrate the majority of lead in the body, the practice has been to remove and dispose of these organs appropriately and to render the remainder of the carcass for animal feed. ${ }^{41}$ The resulting animal feed products would have to be adequately tested for lead and be $\leq 10 \mathrm{mg} / \mathrm{kg}$ on a dry matter basis, the lowest maximum tolerable level for lead according to the National Research Council's (NRC) Mineral Tolerance of Animals. ${ }^{42}$ A sample of tallow was collected at the rendering plant; however this sample contained not only material from the ten dead carcasses from this outbreak but also from an unspecified number of other rendered animals. The tallow sample contained $0.064 \mathrm{mg} / \mathrm{kg}$ lead (as is), a concentration, even when adjusting for moisture, well below the $10 \mathrm{mg} / \mathrm{kg}$ lowest maximum tolerable level for lead defined by the NRC. Other options to dispose of lead-contaminated animals include burial, landfill, incineration, or bioremediation to fertilizer or compost, all with the potential to recycle the lead back into the environment. ${ }^{43}$ Specific guidance and regulation would fall to the jurisdiction of the state and the local Environmental Protection Agency.

\section{Discussion \\ Existing guidelines}

Concern over the accumulation of nonessential metals, such as lead and cadmium, in consumable products and the subsequent implications for human dietary exposure prompted the USDA to conduct a random-sampling of trace metals from tissues of healthy livestock between 1985 and 1986. ${ }^{44}$ Lead and cadmium were rarely detected in the muscle ( $0.2 \%$ to $0.5 \%$ positive in 2314 animals sampled); lead was infrequently detected in liver and kidney, while $46 \%$ and $78 \%$ of liver and kidney respectively were positive for cadmium. Additionally, the Joint Food and Agricultural Organization of the United Nations and the World Health Organization Committee on Food Additives and Contaminants do not list edible tissues from animals as a contributor to human lead exposures, with canned food items providing the bulk of exposure. ${ }^{45}$ The sampling performed by FSIS of the USDA mentioned above in conjunction with monitoring in other countries $^{46,47}$ has indicated that human poisoning through animal residues is unlikely. 
However, as discussed, even trace levels can pose neurotoxic health risk, particularly for young children. ${ }^{19-22}$ Canada and The Netherlands both screen for contamination exceeding established limits for heavy metals; animals are generally condemned, thus limiting entry into the human food supply, and follow up visits are made to determine the source of contamination and prevent future contamination through better management practices. Concern in the US remains for residues in tissues of animals that were exposed to a sublethal dose without development of overt clinical signs. A current study by the USDA FSIS in the National Residue Program for Meat, Poultry and Egg Products has yet to be completed and published but will evaluate lead tissue levels in heifers, boars and stags, dairy cows, mature chickens and market hogs, and determine risk to the consumer. ${ }^{48}$ However, these studies may overlook backyard flocks or livestock that do not enter into market.

\section{Public health threat of subclinical cases}

Taken as a whole, the four cases presented above suggest a real public health threat in California and perhaps nationwide, from backyard chickens and cattle for lead exposure, particularly for the most vulnerable population to toxic effects (young children or pregnant women). The extent of subclinical lead exposures in both family-owned and small commercial operations may be under-diagnosed and precautionary measures are advisable. If there is any concern over lead poisoning in backyard chicken flocks, whole blood and eggs should be submitted to a diagnostic laboratory for analysis. If exposure to lead is identified in a flock or open range herd, every effort must be made to identify the source of contamination in the environment through submission of appropriate samples (such as soil, water, feed, wood chips) and a thorough scouring of the environment for anthropogenic sources. Considering the perception by many backyard chicken owners that lead levels resulting from environmental exposure do not pose a serious health threat ${ }^{49}$ it is especially important to increase awareness and provide resources for testing and assistance with exposure assessment and risk.

Sources of lead may shift depending upon degree of environmental pollution and awareness and local management operations. For example the UK Veterinary Laboratory Agency recently reported the most common sources of lead being discarded batteries and old paint, in particular associated with recycled sawdust and shavings as animal bedding. ${ }^{26,50}$ The UK Contaminants in Food Regulations 2006 specified that lead concentrations should not exceed $0.5 \mathrm{mg} / \mathrm{kg}$ (fresh weight) in offal or $0.1 \mathrm{mg} / \mathrm{kg}$ in meat intended for human consumption. The Veterinary Laboratory Agency suggests animals are at risk for subclinical lead poisoning when exposed to materials with more than $1000 \mathrm{mg} / \mathrm{kg}$ lead dry weight, ${ }^{50}$ but subclinical cases are poorly defined overall.

As the nature and management of operations change over time, more information is needed regarding the toxicokinetics of lead in various species in order to make informed management recommendations. A recent study conducted at the Iowa State University Veterinary Diagnostic Laboratory on lead contamination in a small farm flock of chickens exposed to lead-based paint chips found concentrations in blood (50 to $760 \mathrm{ng} / \mathrm{mL}$ ) strongly correlated with concentrations found in egg yolks (20 to $400 \mu \mathrm{g} / \mathrm{kg}$ ) with shells containing up to $450 \mu \mathrm{g} / \mathrm{kg}$ lead. ${ }^{17}$ As mentioned the highest tissue concentrations occurred in kidney $(1.36 \mathrm{mg} / \mathrm{kg})$ and liver $(0.5 \mathrm{mg} / \mathrm{kg})$ with muscle containing the lowest concentration $(0.28 \mathrm{mg} / \mathrm{kg})$. All animals were subclinical. This study emphasizes the potential public health risk of lead contamination of egg yolks and edible chicken tissue, particularly to children vulnerable to the neurotoxicological effects of trace amounts. As backyard chickens become more popular, it will be important to heighten public awareness about health risks, testing options and management prevention considerations. In addition, other animals can be exposed to similar shavings and chips (dogs, goats, etc) and the problem may be more widespread than suspected.

\section{Management suggestions for lead prevention in chickens}

Specific management recommendations include removal of all potential lead-based materials, elevation of chicken coops above the ground to minimize contamination from soil, and the avoidance of using chicken egg shells in compost because of the potential to re-contaminate the hens or other food sources. No information exists on $t_{1 / 2}$ or withdrawal times. Prospective studies looking at incidence, manifestation, and duration of subclinical or clinical lead exposures in backyard chickens would be advisable to reduce risk of contamination of the food supply. In addition, periodic testing of eggs is advised, particularly for flocks owned by families with young children or pregnant women. The contamination of chickens or eggs suggests a potential source in the environment to which children potentially have access as well. The source should be identified and removed. Finally, any backyard chicken presenting with illness should undergo a heavy metal screen regardless of clinical signs or primary diagnosis. Increased surveillance 
along with good client communication regarding risks must be implemented to adequately address concern.

\section{Economic loss to producers}

In one study, lead poisoning in three herds of cattle accidentally exposed to discarded lead batteries while on pasture was thoroughly evaluated to determine extent and severity of exposure. ${ }^{32}$ Acute death losses were substantial in all three herds. Blood samples were taken from all cattle in herds at the time of diagnosis and then later in two of the three herds to monitor changes over times. Notably asymptomatic lead exposure was observed in all herds (between $4 \%-12 \%$ of animals were asymptomatic with $0.35 \mu \mathrm{g} / \mathrm{mL}$ or greater blood lead concentrations and an even greater percentage was in a high normal range with no symptoms). All asymptomatic cattle potentially exposed to a lead source should be tested before sale or slaughter to minimize lead entry into the public food supply. The median $t_{1 / 2}$ was 63 days. This study emphasized the importance of determined follow up of a herd with lead exposure, and the huge economic cost for the producer both from withdrawal and testing cost. As discussed in the context of the two bovine cases presented here, better understanding of toxicokinetics of lead in cattle and major influencing factors may substantially alter cost and burden for producers and public health officials alike. The development of a biomarker for blood lead concentrations (highly correlated with milk lead levels) could facilitate understanding of toxicokinetics and monitoring of affected herds.

\section{Management suggestions for producers}

Pending the development of such an assay, prevention is key to reduce risk and cost for producers and consumers. Good waste management is critical and all workers should be educated as to the risk from lead contamination to exposed cattle. Petroleum products should be stored appropriately. Trash should be kept out of, and removed from pasture. All pasture should be thoroughly evaluated before turnout. Farm machinery should not be parked near animals, barns, pastures, or farmyards. Any disposal sites should be buried and fenced. Batteries should be disposed of properly. Waste practices and management should also be thoroughly discussed with neighbors and adjacent producers, developing a community awareness and prevention program. ${ }^{51}$

\section{Environmental and public health considerations}

Finally, disposal of condemned or contaminated carcasses poses a potential health threat and a concern for producers and consumers. The potential to contaminate land, soil or water contributes back to the original source problem. Specific guidance as to how to handle affected cases to minimize contamination is advisable, and producers with contaminated carcasses should contact their local environmental regulatory agency. In addition, animals provide a sentinel for lead contamination in the environment, whether widespread or just a local source. In a recent report, cattle deaths from lead poisoning led to the detection of elevated blood lead concentrations in remaining cattle, a dog, a cat, and a pregnant woman living on the farm. ${ }^{7}$ Further testing suggested the lead paint in the house and barn was the most likely source. The environmental source of all lead intoxications must be identified in order to adequately protect human health. The environmental source may pose a threat to more than the immediate herd or family; for example, a contaminated water source would have a much wider impact and should be addressed immediately with the appropriate regulatory body.

Finally, families concerned about acute or chronic exposure from animal products should contact their local health department or physician about testing blood levels, most particularly in children and pregnant women and identification and elimination of the source of contamination is advisable. Testing of eggs and blood levels in livestock is readily done at many animal science programs and veterinary institutions.

\section{Conclusion}

The four cases presented herein illustrate the potential public health threat of subclinical cases of lead intoxication in backyard chickens and cattle. The exposures may not be limited to these species and the trend is not unique to California. Currently, the best approach is good management and prevention of exposure to livestock, pets, and humans alike. It is critical for owners and producers to be aware of potential sources of lead and to be able to identify signs of intoxication. If lead poisoning is diagnosed within a herd or flock, it is important to identify the source and remove the animals or remove the source and evaluate risk of human exposure from either the original source or contaminated animal products. With increasing trends of backyard flocks, it is advisable to implement proactive surveillance with heavy metal screens even in subclinical animals or in any presenting case regardless of clinical signs. We have discussed the uncertainty surrounding appropriate withdrawal time from subclinical cases and the importance of testing, despite cost, to minimize risk for human exposure, particularly to 
children and pregnant women. Producers and public health officials would benefit immensely from the development of an appropriate biomarker of exposure and better-defined withdrawal times.

\section{Acknowledgments}

The authors would like to express their gratitude to Andrew Coggeshall for creating the incidence map, and Dr Shivaprasad for providing one of the images. We are also grateful to have been able to use case-related information from Drs Anderson, Barr, Moeller, Poppenga, Senties, and Tawde. Special thanks go to the technicians of the Elemental Analysis Group of the California Animal Health and Food Safety Toxicology Laboratory for their technical assistance.

\section{Disclosure}

The authors have no conflicts of interest to declare.

\section{References}

1. Humphreys DJ. Effects of exposure to excessive quantities of lead on animals. Br Vet J. 1991;147(1):18-30.

2. Mahaffey KR. Quantities of lead producing health effects in humans: sources and bioavailability. Environ Health Perspect. 1977;19: 285-295.

3. Kucera E. Dogs as indicators of urban lead distribution. Environ Monit Assess. 1988;10(1):51-57.

4. Swarup D, Patra RC, Naresh R, Kumar P, Shekhar P. Blood lead levels in lactating cows reared around polluted localities; transfer of lead into milk. Sci Total Environ. 2005;349(1-3):67-71.

5. Balagangatharathilagar M, Swarup D, Patra RC, Dwivedi SK. Blood lead level in dogs from urban and rural areas of India and its relation to animal and environmental variables. Sci Total Environ. 2006;359(1-3): $130-134$.

6. Ceruti R, Ghisleni G, Ferretti E, Cammarata S, Sonzogni O, Scanziani E. Wild rats as monitors of environmental lead contamination in the urban area of Milan, Italy. Environ Pollut. 2002;117(2):255-259.

7. Bischoff K, Priest H, Mount-Long A. Animals as sentinels for human lead exposure: a case report. J Med Toxicol. 2010;6(2):185-189.

8. Jelinek CF. Levels of lead in the United States food supply. J Assoc Off Anal Chem. 1982;65(4):942-946.

9. Koller K, Brown T, Spurgeon A, Levy L. Recent developments in low-level lead exposure and intellectual impairment in children. Environ Health Perspect. 2004;112(9):987-994.

10. Varga A, Puschner B. Retrospective study of cattle poisonings in California: recognition, diagnosis, and treatment. Veterinary Medicine: Research and Reports. 2012;3(1):111-127.

11. Baker JC. Lead poisoning in cattle. Vet Clin North Am Food Anim Pract. 1987;3(1):137-147.

12. Swarup D, Patra RC, Naresh R, Kumar P, Shekhar P. Blood lead levels in lactating cows reared around polluted localities; transfer of lead into milk. Sci Total Environ. 2005;347(1-3):106-110.

13. Sharma RP, Street JC, Shupe JL, Bourcier DR. Accumulation and depletion of cadmium and lead in tissues and milk of lactating cows fed small amounts of these metals. J Dairy Sci. 1982;65(6): 972-979.

14. Salisbury RM, Staples ELJ, Sutton M. Lead poisoning of chickens. NZVJ. 1958;6(1):2-7.

15. Kaufer I. Chronic lead poisoning in young chickens. Berl Munch Tierarztl Wochenschr. 1979;92(19):380-383.

16. Bakalli RI, Pesti GM, Ragland WL. The magnitude of lead toxicity in broiler chickens. Vet Hum Toxicol. 1995;37(1):15-19.
17. Trampel DW, Imerman PM, Carson TL, Kinker JA, Ensley SM. Lead contamination of chicken eggs and tissues from a small farm flock. J Vet Diagn Invest. 2003;15(5):418-422.

18. Scelfo J. High lead found in city-sourced eggs. The New York Times. October 10, 2012;Dining \& Wine:D5.

19. Canfield RL, Henderson CR Jr, Cory-Slechta DA, Cox C, Jusko TA, Lanphear BP. Intellectual impairment in children with blood lead concentrations below 10 microg per deciliter. $N$ Engl J Med. 2003; 348(16): $1517-1526$.

20. Leads from the MMWR. Preventing lead poisoning in young children - United States. JAMA. 1985;253(15):2182-2183.

21. Preventing lead poisoning in young children - United States. $M M W R$ Morb Mortal Wkly Rep. 1985;34(5):66-68, 73.

22. Preventing lead poisoning in young children. A statement by the Center for Disease Control. J. Pediatr. 1978;93(4):709-720.

23. Schlerka G, Tataruch F, Hogler S, et al. Acute lead poisoning in cows due to feeding of lead contaminated ash residue. Berl Munch Tierarztl Wochenschr. 2004;117(1-2):52-56.

24. Lead poisoning in cattle associated with car batteries and sump oil. Vet Rec. 2011;169(7):173-176.

25. Burren BG, Reichmann KG, McKenzie RA. Reduced risk of acute poisoning in Australian cattle from used motor oils after introduction of lead-free petrol. Aust Vet J. 2010;88(6):240-241.

26. Sharpe RT, Livesey CT. Lead poisoning in cattle and its implications for food safety. Vet Rec. 2006;159(3):71-74.

27. Lemos RA, Driemeier D, Guimaraes EB, Dutra IS, Mori AE, Barros CS. Lead poisoning in cattle grazing pasture contaminated by industrial waste. Vet Hum Toxicol. 2004;46(6):326-328.

28. Dwivedi SK, Swarup D, Dey S, Patra RC. Lead poisoning in cattle and buffalo near primary lead-zinc smelter in India. Vet Hum Toxicol. 2001;43(2):93-94.

29. Preece BE. Lead poisoning in cattle at turnout. Vet Rec. 1995;136(18): $475-476$.

30. Hammond PB, Aronson AL. Lead poisoning in cattle and horses in the vicinity of a smelter. Ann NY Acad Sci. 1964;111:595-611.

31. Yonge KS, Morden BB. Bovine lead poisoning in Alberta: a management disease. Can Vet J. 1989;30(1):42-45.

32. Waldner C, Checkley S, Blakeley B, Pollock C, Mitchell B. Managing lead exposure and toxicity in cow-calf herds to minimize the potential for food residues. J Vet Diagn Invest. 2002;14:481-486.

33. Rumbeiha WK, Braselton WE, Donch D. A retrospective study on the disappearance of blood lead in cattle with accidental lead toxicosis. J Vet Diagn Invest. 2001;13(5):373-378.

34. Galey FD, Slenning BD, Anderson ML, et al. Lead concentrations in blood and milk from periparturient dairy heifers seven months after an episode of acute lead toxicosis. J Vet Diagn Invest. 1990;2(3): $222-226$.

35. Kang HG, Bischoff K, Ebel JG, Cha SH, McCardle J, Choi CU. Comparison of blood lead and blood and plasma delta-aminolevulinic acid concentrations as biomarkers for lead poisoning in cattle. $J$ Vet Diagn Invest. 2010;22(6):903-907.

36. Franson JC. Interpretation of tissue lead residues in birds other than waterfowl. In: Beyer WN, Heinz GH, Redmon-Norwood AW, editors. Environmental Contaminants in Wildlife: Interpreting Tissue Concentrations. Boca Raton, FL: CRC Press; 1996:265-279.

37. Anonymous. CDPH warns consumers not to eat five preserved plum/ prune products 2012. Available from: http:/www.cdph.ca.gov/Pages/ NR12-060.aspx. Accessed December 18, 2012.

38. Anonymous. Guideline for the Identification and Management of Lead Exposure in Pregnant and Lactating Women. Atlanta, GA: Centers for Disease Control and Prevention; Nov 2010. Available at: http://www.cdc.gov/nceh/lead/publications/leadandpregnancy 2010.pdf.

39. Anonymous. Screening Regulations: Standard of care on screening for childhood lead poisoning 2010; http://www.cdph.ca.gov/programs/ CLPPB/Pages/ScreenRegs-CLPPB.aspx. Accessed December 19, 2012 . 
40. Oskarsson A, Jorhem L, Sundberg J, Nilsson NG, Albanus L. Lead poisoning in cattle - transfer of lead to milk. Sci Total Environ. 1992; 111(2-3):83-94.

41. Hassan AA, Rylander C, Brustad M, Sandanger TM. Level of selected toxic elements in meat, liver, tallow and bone marrow of young semi-domesticated reindeer (Rangifer tarandus tarandus L.) from Northern Norway. Int J Circumpolar Health. 2012; 71:1-7.

42. The National Research Council U. Mineral tolerance of animals. 2nd rev. ed. Washington, DC: The National Academies Press; 2005. $10-14$.

43. Anonymous. Innovative Uses of Compost: Bioremediation and Pollution Prevention. Washington, DC: US Environmental Protection Agency, Solid Waste and Emergency Response; 1997.

44. Coleman ME, Elder RS, Basu P. Trace metals in edible tissues of livestock and poultry. JAOAC Int. 1992;75(4):615-625.

45. Galal-Gorchev H. Twenty-second Session of Joint FAO/WHO Food Standards Programme Codex Committee on Food Additives and Contaminants. Vol CX/FAC 90/5-Add.1. The Hague, Netherlands: WHO; 1990.
46. Zmudski J, Bratton GR, Womac C, Rowe L. Lead poisoning in cattle: reassessment of the minimum toxic oral dose. Bull Environ Contam Toxicol. 1983;30(4):435-441.

47. Korsrud GO, Meldrum JB, Salisbury CD, Houlahan BJ, Saschenbrecker PW, Tittiger F. Trace element levels in liver and kidney from cattle, swine and poultry slaughtered in Canada. Can J Comp Med. 1985;49(2):159-163.

48. O'Keefe M, Edwards SR, Blanchard A, Miraglia A. United States National Residue Program for Meat, Poultry, and Egg Products 2012 Residue Sampling Plans. Washington, DC: United States Department of Agriculture, Food Safety and Inspection Service 2012.

49. Anonymous. Lead found in backyard chicken eggs. BackYard Chickens 2012; http://www.backyardchickens.com/t/714566/lead-found-inbackyard-chickens-eggs. Accessed December 18, 2012.

50. Payne J, Otter A, Cranwell M, Jones J, Wessels M, Whitaker K. Lead poisoning associated with recycled wood products. Vet Rec. 2008;162(6):191-192.

51. Anonymous. Lead poisoning in cattle. 2001. Available from: http:// www.1.agric.gov.ab.ca/\$department/deptdocs.nsf/all/agdex 791 . Accessed December 18, 2012.
Veterinary Medicine: Research and Reports

\section{Publish your work in this journal}

Veterinary Medicine: Research and Reports is an international, peer-reviewed, open access journal publishing original research, case reports, editorials, reviews and commentaries on all areas of veterinary medicine. The manuscript management system is completely online and includes a very quick and fair peer-review system.

\section{Dovepress}

Visit http://www.dovepress.com/testimonials.php to read real quotes from published authors. 